\title{
High-performance end milling of aluminum alloy: Influence of different serrated cutting edge tool shapes on the cutting force
}

\author{
Burek, J. ${ }^{a}$, Plodzien, M. ${ }^{a}$, Zylka, L., ${ }^{a}$, Sulkowicz, P. ${ }^{a}$ \\ ${ }^{a}$ Department of Manufacturing Techniques and Automation, The Faculty of Mechanical Engineering and Aeronautics, \\ Rzeszow University of Technology, Rzeszow, Poland
}

\begin{abstract}
A B S T R A C T
The article presents the results of experimental studies in high performance milling of AlZn5.5MgCu aluminum alloy. The tests were performed with the use of end mill cutters with different serrated shapes of the cutting edge. End mills with continuous, interrupted and wavy with varied profile radius were used. The tests were conducted on a DMG's DMU 100 MonoBlock machining center with cutting force components measurement in workpiece system capabilities. The experimental tests were carried out using varied radial depth of cut $a_{e}$ and feed per tooth $f_{z}$ parameters according to applied three-level full design of experiment. The relationships between $a_{e}$ and $f_{z}$ parameters and cutting force components for various cutting edge shapes were determined. A continuous cutting edge was adopted as a reference shape. Based on the results of the tests, cutting force components models for analyzed cutting edge shapes were determined. A comparative analysis between the developed models and relationships was conducted. The study proved that when adopting end mills with serrated cutting edges, lower cutting force components are obtained, in comparison with cutters with continuous cutting edges. The results also showed that for end mills with serrated cutting edges radial depth of cut $a_{e}$ has a negligible influence on the feed force component $F_{f}$. The results proved, that end mills with serrated cutting edges should be used in high performance machining, where high values of $a_{e}$ and $f_{z}$ parameters are adopted. Furthermore, machining of thin-walled workpieces can be a potential application of these end mills, as lower values of cutting force components reduce the risk of deformation of milled thin walls.
\end{abstract}

\author{
ARTICLE INFO \\ Keywords: \\ High performance milling; \\ Aluminum alloy (AlZn5.5MgCu); \\ Cutting force; \\ Modelling; \\ End mill cutter; \\ Serrated cutting edge \\ *Corresponding author: \\ zylka@prz.edu.pl \\ (Zylka, L.)
}

Article history:

Received 9 September 2019

Revised 2 December 2019

Accepted 4 December 2019

\section{References}

[1] Burek, J., Zylka, L., Plodzien, M., Gdula, M., Sulkowicz, P. (2018). The influence of the cutting edge shape on high performance cutting, Aircraft Engineering and Aerospace Technology, Vol. 90, No. 1, 134-145, doi: 10.1108/ AEAT-11-2015-0243.

[2] Budak, E. (2006). Analytical models for high performance milling. Part I: Cutting forces, structural deformations and tolerance integrity, International Journal of Machine Tools and Manufacture, Vol. 46, No. 12-13, 1478-1488, doi: 10.1016/i.ijmachtools.2005.09.009.

[3] Masood, I., Jahanzaib, M., Haider, A. (2016). Tool wear and cost evaluation of face milling grade 5 titanium alloy for sustainable machining, Advances in Production Engineering \& Management, Vol. 11, No. 3, 239-250, doi: 10.14743/apem2016.3.224.

[4] Santos, M.C., Machado, A.R., Sales, W.F., Barrozo, M.A.S., Ezugwu, E.O. (2016). Machining of aluminum alloys: A review, The International Journal of Advanced Manufacturing Technology, Vol. 86, No. 9-12, 3067-3080, doi: 10.1007/s00170-016-8431-9. 
[5] Tang, A., Liu, Z. (2008). Deformations of thin-walled plate due to static end milling force, Journal of Materials Processing Technology, Vol. 206, No. 1-3, 345-351, doi: 10.1016/i.jmatprotec.2007.12.089.

[6] Ren, S., Long, X., Meng, G. (2018). Dynamics and stability of milling thin walled pocket structure, Journal of Sound and Vibration, Vol. 429, 325-347, doi: 10.1016/i.jsv.2018.05.028.

[7] Borojević, S., Lukić, D., Milosević, M., Vukman, J., Kramar, D. (2018). Optimization of process parameters for machining of Al 7075 thin-walled structures, Advances in Production Engineering \& Management, Vol. 13, No. 2, 125135, doi: 10.14743/apem2018.2.278.

[8] Burek, J., Żyłka, Ł., Płodzień, M., Sułkowicz, P., Buk, J. (2017). The effect of the cutting edge helix angle of the cutter on the process of chips removing from the cutting zone, Mechanik, Vol. 11, 962-964, doi: 10.17814/ mechanik.2017.11.152.

[9] Kuczmaszewski, J., Pieśko, P., Zawada-Michałowska, M. (2017). Influence of milling strategies of thin-walled elements on effectiveness of their manufacturing, Procedia Engineering, Vol. 182, 381-386, doi: 10.1016/ j.proeng.2017.03.117.

[10] Shamsuddin, K.A., Ab-Kadir, A.R., Osman, M.H., (2013). A comparison of milling cutting path strategies for thinwalled aluminium alloys fabrication, The International Journal of Engineering \& Science, Vol. 2, No. 3, 1-8.

[11] Guo, Y., Lin, B., Wang, W. (2019). Modeling of cutting forces with a serrated end mill, Mathematical Problems in Engineering, Vol. 2019, Article ID 1796926, doi: 10.1155/2019/1796926.

[12] Tsai, M.Y., Chang, S.Y., Hung, J.P., Wang, C.C. (2016). Investigation of milling cutting forces and cutting coefficient for aluminum 6060-T6, Computers \& Electrical Engineering, Vol. 51, 320-330, doi: 10.1016/j.compeleceng.2015. $\underline{09.016}$.

[13] Kaneko, K., Nishida, I., Sato, R., Shirase, K. (2018). Virtual milling force monitoring method based on in-process milling force prediction model to eliminate predetermination of cutting coefficients, Procedia CIRP, Vol. 77, 2225, doi: 10.1016/i.procir.2018.08.196.

[14] Karpuschewski, B., Kundrák, J., Varga, G., Deszpoth, I., Borysenko, D. (2018). Determination of specific cutting force components and exponents when applying high feed rates, Procedia CIRP, Vol. 77, 30-33, doi: 10.1016/ j.procir.2018.08.199.

[15] Li, D., Cao, H., Zhang, X., Chen, X., Yan, R. (2019). Model predictive control based active chatter control in milling process, Mechanical Systems and Signal Processing, Vol. 128, 266-281, doi: 10.1016/i.ymssp.2019.03.047.

[16] Yang, Y., Li, M., Li, K.R. (2014). Comparison and analysis of main effect elements of machining distortion for aluminum alloy and titanium alloy aircraft monolithic component, The International Journal of Advanced Manufacturing Technology, Vol. 70, No. 9-12, 1803-1811, doi: 10.1007/s00170-013-5431-x.

[17] Liu, X.-W., Cheng, K., Webb, D., Luo, X.-C. (2002). Improved dynamic cutting force model in peripheral milling. Part I: Theoretical model and simulation, The International Journal of Advanced Manufacturing Technology, Vol. 20, No. 9, 631-638, doi: $10.1007 / \mathrm{s} 001700200200$.

[18] Dombovari, Z., Altintas, Y., Stepan, G. (2010). The effect of serration on mechanics and stability of milling cutters, International Journal of Machine Tools and Manufacture, Vol. 50, No. 6, 511-520, doi: 10.1016/j.ijmachtools.2010. $\underline{03.006}$.

[19] Merdol, S.D., Altintas, Y. (2004). Mechanics and dynamics of serrated cylindrical and tapered end mills, Journal of Manufacturing Science and Engineering, Vol. 126, No. 2, 317-326, doi: 10.1115/1.1644552.

[20] Koca, R., Budak, E. (2013). Optimization of serrated end mills for reduced cutting energy and higher stability, Procedia CIRP, Vol. 8, 570-575, doi: 10.1016/j.procir.2013.06.152.

[21] Rekers, S., Auerbach, T., Veselovac, D., Klocke, F. (2015). Cutting force reduction in the milling of aluminum alloys with serrated cutting tool edges, Journal of Machine Engineering, Vol. 15, No. 4, 27-36.

[22] Campomanes, M.L. (2002). Kinematics and dynamics of milling with roughing end mills, In: Dudzinski, D., Molinari, A., Schulz, H. (eds), Metal Cutting and High Speed Machining, Kluwer Academic Publishers Plenum Press, New York, USA, 129-140.

[23] Grabowski, R., Denkena, B., Köhler, J. (2014). Prediction of process forces and stability of end mills with complex geometries, Procedia CIRP, Vol. 14, 119-124, doi: 10.1016/i.procir.2014.03.101.

[24] Sultan, A.A., Okafor, A.C. (2016). Effects of geometric parameters of wavy-edge bull-nose helical end-mill on cutting force prediction in end-milling of Inconel 718 under MQL cooling strategy, Journal of Manufacturing Processes, Vol. 23, 102-114, doi: 10.1016/i.jmapro.2016.05.015.

[25] Tehranizadeh, F., Budak, E. (2017). Design of serrated end mills for improved productivity, Procedia CIRP, Vol. 58, 493-498, doi: 10.1016/i.procir.2017.03.256. 


\section{APEM}

\title{
Visokozmogljivo rezkanje aluminijaste zlitine: Vpliv različno nazobčanih oblik orodja na rezalno silo
}

\author{
Burek, J. ${ }^{a}$, Plodzien, M. ${ }^{a}$, Zylka, L. ${ }^{a}{ }^{,}$, Sulkowicz, P. ${ }^{a}$ \\ ${ }^{a}$ Department of Manufacturing Techniques and Automation, The Faculty of Mechanical Engineering and Aeronautics, \\ Rzeszow University of Technology, Rzeszow, Poland
}

\section{POVZETEK}

$\mathrm{V}$ članku so predstavljeni rezultati eksperimentalnih raziskav pri rezkanju visokozmogljive aluminijeve zlitine AlZn5.5MgCu. Preskusi so bili izvedeni z uporabo rezkarjev z različno nazobčanimi oblikami rezalnega roba. Uporabljeni so rezkarji z neprekinjenim, prekinjenim in raznoliko valovitim profilom. Preizkusi so bili izvedeni na obdelovalnem centru DMG (DMU 100 MonoBlock), komponente rezalne sile pa so bile merjene v zmogljivostih sistema obdelovanca. Eksperimentalni preizkusi so bili izvedeni z uporabo različnih radialnih globin rezanja $a_{e}$ in podajanja na zob $f_{z} \mathrm{v}$ skladu s trinivojsko polno zasnovo eksperimenta. Za različne oblike rezalnega roba je bila določena povezava med parametroma $a_{e}$ in $f_{z}$ in komponentami rezalne sile. Kot referenčna oblika je bil izbran neprekinjen rezalni rob. Za analizirane oblike rezalnih robov smo na podlagi rezultatov preizkusov vzpostavili modele komponent rezalne sile. Izvedena je bila primerjalna analiza med razvitimi modeli in povezavami. Študija je dokazala, da dobimo pri uporabi rezkarjev z nazobčanimi rezalnimi robovi nižje komponente rezalne sile $\mathrm{v}$ primerjavi z rezkarji z neprekinjenimi rezalnimi robovi. Rezultati so pokazali tudi, da ima za rezkar z nazobčanimi rezalnimi robovi radialna globina reza $a_{e}$ zanemarljiv vpliv na komponento podajalne sile $F_{f}$. Rezultati so dokazali, da je treba rezkarje $\mathrm{z}$ nazobčanimi rezalnimi robovi uporabiti pri visokozmogljivi obdelavi, kjer so uporabljene visoke vrednosti $a_{e}$ in $f_{z}$ parametrov. Poleg tega je obdelava tankostenskih obdelovancev potencialno lahko področje uporabe teh rezkarjev, saj nižje vrednosti komponent rezalne sile zmanjšujejo tveganje deformacije rezkanih tankih sten.

\section{PODATKI O ČLANKU}

Ključne besede:

Rezkanje z visoko zmogljivostjo; Aluminijeva zlitina (AlZn5.5MgCu); Rezalna sila;

Modeliranje;

Rezkar;

Nazobčan rezalni rob

*Kontaktna oseba: zylka@prz.edu.pl (Zylka, L.)

Zgodovina članka:

Prejet 9. septembra 2019

Popravljen 2. decembra 2019

Sprejet 4. decembra 2019 